Please do not remove this page

RMIT

UNIVERSITY

\title{
Failing to live up to the promise: the politics of equal pay in 'new' workplace and industrial relations institutions
}

Macdonald, Fiona; Charlesworth, Sara

https://researchrepository.rmit.edu.au/esploro/outputs/9921863408801341/filesAndLinks?institution=61RMIT_INST\&index=null

Macdonald, F., \& Charlesworth, S. (2018). Failing to live up to the promise: the politics of equal pay in "new" workplace and industrial relations institutions. Australian Journal of Political Science, 53(4), 446-462. https://doi.org/10.1080/10361146.2018.1502256

Document Version: Accepted Manuscript

Published Version: https://doi.org/10.1080/10361146.2018.1502256

Repository homepage: https://researchrepository.rmit.edu.au

(C) 2018 Australian Political Studies Association

Downloaded On 2023/04/26 19:57:50 +1000

Please do not remove this page 


\title{
Political Science
}

\section{Failing to live up to the promise: equal pay in 'new' workplace and}

\section{industrial relations institutions.}

\author{
Fiona Macdonald, School of Management, RMIT University \\ Sara Charlesworth, School of Management, RMIT University
}

\begin{abstract}
Workplace and industrial relations regulations are key sites for policy intervention to address Australia's gender pay gap, which, at 15.3 per cent, is almost as large as it was in 1997. In both the Fair Work Act 2009 (Cth) and the Workplace Gender Equality Act 2012 (Cth) the goal of equal pay has a more central place than it did in predecessor legislation. In particular, the Fair Work Act has the potential to deliver more gender-equitable wage structures through addressing systemic gender-based undervaluation at the industry level. Adopting a feminist institutional approach this article examines equal pay policy in the operations of workplace and industrial relations regulation to ask why, despite some recent successes, this potential appears unlikely to be realised.
\end{abstract}

Keywords: Equal pay, gender equality, feminist institutionalism, industrial relations, Workplace Gender Equality Act 2012, Fair Work Act 2009

\section{Introduction}

The size of gender pay gap in Australia has changed little in the last two decades. In November 2017 it was 15.3 per cent, according to the Workplace Gender Equality Agency (WGEA), with this figure based on average weekly ordinary full-time earnings data from the 


\section{Pre-print version, article accepted for publication in Australian Journal of}

\section{Political Science}

Australian Bureau of Statistics (WGEA 2018a, 3). The gender pay gap is just one percentage point lower than it was 20 years prior in 1997 (16.3 per cent) (WGEA 2018a, 3). There are multiple factors contributing to the gender pay gap that lie beyond the workplace and the full range of strategies for reducing the pay gap include addressing gender inequalities, stereotypes and arrangements at individual, family and societal levels (European Commission 2009). Nevertheless, addressing the organisation of the labour market and structures of pay and reward to achieve structural change in workplaces and the industrial system are critical to reducing the gender pay gap and progressing gender equality (Rubery and Koukiadaki 2016, 1).

Substantive gender equality, that goes beyond equal opportunity to transform current gendered arrangements disadvantaging women, requires attention to the institutional bases of systemic inequality and it requires economic redistribution (Fredman 2008; Rimmer and Sawer 2016, 745). In both respects Australia has two recently established and potentially powerful mechanisms for addressing gender inequality in employment and the labour market through reducing the gender pay gap. The Workplace Gender Equality Act 2012 (Cth) (WGE Act) is designed to foster proactive strategies to address gender inequalities at the workplace level and it was established with a much stronger outcomes focus than the legislation it replaced - the Equal Opportunity for Women in the Workplace Act 1999 (Cth) (EOWW Act)-, which was widely regarded as ineffective (KPMG 2010, 125-128). The Fair Work Act 2009 (Cth) (FW Act) includes equal remuneration provisions that have application at the industry, sector and occupational levels and that were designed to overcome limitations of provisions in earlier industrial relations (IR) legislation, including through explicit removal of the requirement 'to demonstrate (as a threshold issue) that there has been some kind of 


\section{Pre-print version, article accepted for publication in Australian Journal of Political Science}

discrimination involved in the setting of remuneration' (House of Representatives 2008, 189, 1192).

In this article we explore the extent to which the WGE Act and the FW Act have realised their apparent potential as reforms for gender pay equity. We argue that while, as gender reforms, both pieces of legislation appeared to have significant potential for progressing gender pay equity, this potential has been met only partially.

In considering how and why the two 'institutional innovations' may be failing to meet their potential to progress gender equality through gender pay equity we draw on insights from Fiona Mackay’s (2014) feminist institutionalism. In particular, Mackay’s $(2014,552)$ concept of 'nested newness' provides a framework for considering how 'old' gender practices, norms and expectations in formal and informal institutional rules might limit the potential of the gender reforms of the 'new' institutions of the WGE Act and FW Act. Drawing on the idea of nested newness we address the following questions: what, if any, legacies do the new institutions carry from the past that influence their operations; what is the nature of the gendered institutional environments within which they are embedded; how does the gendered context influence their responses to pay equity; and, finally, what change for gender equality might we expect from these institutions in the future based on their operations to date?

In the next section we outline the feminist institutionalist framework guiding our analysis of the legislative mechanisms and their administrative and arbitral processes for equal pay. In the following section, we present our analyses of the operations of the new WGE Act and FW Act in addressing equal pay in the first years of their establishment. In a brief concluding section we reflect on the potential for further positive change for gender equality through these mechanisms. 


\section{Background and method}

'Feminist institutionalism' draws on common concerns of different strands of new institutionalism (NI) and on feminist political science to understand the dynamics of political stability and change (Krook and Mackay 2011, 13-14; Mackay, Kenny and Chappell 2010). Conceptualised as the rules that structure political and social life, institutions are understood to encompass both structural features and formal rules along with ideas, codes of behaviour, beliefs and attitudes (Krook and Mackay 2011). While a key concern of NI scholarship has been with institutional continuity and change and the persistence of particular formal institutional patterns, feminist political scientists have contributed to this literature by highlighting the embedded gender dimensions of institutions and seeking to identify the gender norms constraining change in institutions (Mackay et al. 2010).

In taking a feminist institutionalism approach we draw in particular on Fiona Mackay’s concept of 'nested newness' which was developed to better understand the possibilities and limits of new institutions and, in particular, to understand 'why gender reforms should be so vulnerable to regress, even in new institutional contexts'(Mackay 2014, 552). The concept of nested newness is an attempt to capture the ways in which the new is embedded in 'time, sequence and its institutional environment' and how this influences the development of institutions and their capacity for breaking with the past (Mackay 2014, 552). Institutional creation is often 'best understood as bounded innovation within an existing system' due to the influence of old legacies (material, cognitive and normative, and including patterns of power distributions), the differing goals of multiple institutional designers, and ongoing dynamics with other institutions (Mackay 2014, 553). The early actions and decisions taken in a new 


\section{Pre-print version, article accepted for publication in Australian Journal of Political Science}

institutional context can be the most important as these can establish and limit future directions due to a tendency to the status quo or 'path dependency' (Pierson 2004, 45). Drawing on these ideas from broader NI scholarship Mackay also posits that, when institutions are new, they face multiple challenges related to their newness and, in this 'postdesign' stage, institutional actors will look to the external environment to achieve legitimacy through endorsement of external power holders. Actors can either seek to change the gendered status quo, a risky strategy if at odds with the external environment, or they can fall back on old authoritative ways of working endorsed by power holders. So, institutional change involving gender reforms can function as a 'gendered liability' explaining why it is hard to make these reforms 'stick' (Mackay 2014, 568).

Mackay $(2014,554)$ stresses the 'importance of attending to the ways in which gendered institutions are enacted and instantiated ... by gendered actors using formal and informal rules and norms and new and old institutional elements'. Institutional actors can actively resist or passively neglect institutional innovation, 'forgetting' new rules or drawing on old informal rules modifying newness and effectively undoing reforms that challenge the status quo (Mackay 2014, 555)

Both the WGE Act and FW Act appear to contain innovations with potential to change the gendered status quo. Applying insights from Mackay's feminist institutional scholarship we would expect to find considerable challenge to the innovations of the FW Act and WGE Act. While their early operations might provide the best chance for these new institutions to demonstrate their potential for positive change to progress gender equality it is also the period in which the old is most likely to constrain and limit the possibilities for change, with adherence to old gender practices, norms and expectations being key aspects of this. 


\section{Political Science}

To explore the gender reforms for equal pay in the WGE Act and the FW Act and the extent to which these represent breaks or not from the past we utilise Carol Bacchi's interpretive policy analysis approach. This 'what's the problem represented to be' (WPR) approach starts from the assumption that 'policies and policy proposals contain implicit representations of what is considered to be the problem' and these affect what gets done about these problems (Bacchi 2016, 21). By probing unexamined assumptions within policies and policy proposals (as the postulated problem 'solutions') it is possible to expose the meaning creation in policy processes and policy design, interrupting "the presumption that "problems" are fixed and uncontroversial starting points for policy development' (Bacchi 2016, 23, see also Bacchi 1999, 5-8). Critical scrutiny of policies and policy proposals following the WPR approach entails asking questions about: what the problem is represented to be; what assumptions underlie this representation; how the representation has come about; what is left unproblematic; what effects are produced; and how can it be disrupted and replaced (Bacchi 2016, 22). In our examination of the pay equity reforms of the WGE Act and the FW Act we apply the WPR approach to representations of gender equality and gender pay equity in the formal rules or texts of the legislation and in policy statements of the institutional actors, who are the individuals and groups who influence the operation of the legislation and regulation. We use this exploration of policy constructions within the texts of the legislation and by institutional actors to identify institutional gender norms, to assess how 'new' the WGE Act and FW Act and their gender reforms are and to expose the ways in which the institutional innovations are embraced or resisted by various actors.

Our analysis of the WGE Act design and operations focussed on gender pay equity/equal pay and drew on: the text of the WGE Act and related regulatory instruments and amendments; 


\section{Pre-print version, article accepted for publication in Australian Journal of Political Science}

reports and statements of the administering agency WGEA; and equivalent documents relating to the earlier EOWW Act. We identified key actors shaping these institutions and their operations through examination of reports and submissions to parliamentary inquiries, reports of consultations and reviews of the legislation and other publicly available actor statements, including some reported in earlier academic analyses (see Authors 2013; Strachan et al. 2004; Strachan et al. 2007; Sutherland 2013). Key actors include the responsible ministers under several Federal governments, government departments, individual employers and peak employer bodies, women's groups and the Australian Council of Trade Unions (ACTU). For the 2013-2017 period we analysed public statements in Australian-based media outlets mentioning 'gender equality' and 'WGEA' and on actor organisations' websites. Our analysis of the FW Act focussed on the equal remuneration provisions in the new legislation. Our data included the texts of decisions of the Fair Work Commission (FWC) including minimum wage and Modern Award reviews and equal pay cases and available statements and submissions of institutional actors, with the key actors including employers, trade unions and governments.

\section{The Workplace Gender Equality Act}

Australia has had a specific legal mechanism to address gender inequality in individual workplaces for over 30 years. The current mechanism is the WGE Act and it applies to all private sector and non-government organisations with 100 or more employees. At the time it was enacted in 2012 under a Labor government, the WGE Act appeared, on paper, to have the potential to be a much more effective regulatory strategy for progressing equal pay than its predecessor, the EOWW Act. This is apparent in the representation of the problems the 


\section{Pre-print version, article accepted for publication in Australian Journal of Political Science}

WGE Act is designed to address and, arising from this, the possible strategies for addressing the problems.

The first object of the WGE Act (s 2A (a)) is 'to promote and improve gender equality (including equal remuneration between women and men) in employment and in the workplace'. Thus, the problem is represented as gender inequality with unequal remuneration central to the realisation of this objective. This signifies a significant break from the predecessor EOWW Act (s 2A), in which unequal opportunity and discrimination were represented as the problems with no explicit reference to gender equality or equal pay. Further, while the objects of the new WGE Act include to improve gender equality, the earlier EOWW Act (s 2A) only aimed to promote the principle of merit-based employment, elimination of discrimination and provision of equal opportunity. So, the WGE Act contains a representation of gender inequality as much more than a problem of equal opportunity: in relation to unequal pay the problem to be addressed is unequal pay outcomes (see also Sutherland 2013).

Unlike the earlier EOWW Act, the WGE Act appears to represent gender inequality as a problem that is entrenched and systemic and unlikely to be remedied by simply encouraging individual employers to take action to remove barriers to equal opportunity. This is evident through a comparison of the formal rules of the EOWW Act and the WGE Act that place requirements on employers. The EOWW Act (s 8) required individual employers to report annually on their 'equal opportunity for women in the workplace' programs that had to include workplace profiles, priority issues, actions taken and an evaluation of their effectiveness... Employers were required to report on processes only, rather than having to demonstrate any progress toward gender equality. Those demonstrating good practice could 


\section{Pre-print version, article accepted for publication in Australian Journal of Political Science}

have their reporting requirements reduced or waived. Underlying these requirements was an assumption that individual employers would take responsibility for 'fixing' gender inequality by going through a process of review and self-assessment, identifying barriers to equal opportunities and taking action to remove them (Strachan et al. 2004). There was also some reliance on the role of public scrutiny as a motivator for individual employers to take action, with reports made publicly available (on request). However, there were many gaps in reporting (EOWA 2009; KPMG 2010; Strachan et al. 2007). There were limited requirements for information or standardised reporting, and it was not possible for reports to be collated to provide an overall picture of workforce profiles, employer issues and strategies or to enable comparisons of organisations (Smith and Hayes 2015, 194; Strachan et al. 2007). So, to a large extent the problem to be addressed was identified as a lack of workplace equal opportunity programs, with the solution being to encourage employers to demonstrate they had removed formal barriers to equal opportunity. The absence of strong compliance measures represented the problem as a voluntary responsibility of individual employers. An estimated third of relevant employers did not report at all (KPMG 2010, 126) meaning, effectively, that reporting was discretionary under the informal rules of the EOWW Act.

Under the new WGE Act employers continue to report to the administering agency, now WGEA. However, reporting is more outcomes focussed and it is tightly specified around a framework of 'gender equality indicators', one of which is equal remuneration (WGE Act $2012 \mathrm{~s} 3$ ). Employers are required to provide detailed data on employee remuneration by gender and to report on whether any action has been taken to identify or address any gender pay gaps in their workforces. The concept of equal opportunity for women in the workplace has been removed (Parliament of Australia 2010) and formally the problem to be addressed is now one of gender inequality in outcomes. 
The WGE Act appears to have been designed to address substantive gender inequality including an unequal pay problem that is now represented as one that requires action from employers. The inclusion of a requirement for the responsible government minister to set mandatory minimum standards for employer performance in relation to each of a number of gender equality indicators identified in the legislation on paper is a significant departure from the EOWW Act. At the time of the WGE Act inception it was anticipated that the minimum standards would be developed on the basis of the evidence provided through the new standardised reporting process. With the capacity to collect, analyse and aggregate data from all large employers, the WGEA, in consultation with businesses, employee organisations and gender equality specialists, would set industry or other sector-specific benchmarks and minimum standards and would focus efforts on assisting employers 'most in need' (Parliament of Australia 2010, 29). WGEA was provided with increased funding to develop and promulgate benchmarks and the compliance framework was strengthened with a new requirement for employers to meet minimum standards in the second full year of operation of the WGE Act, 2014-2015 (WGEA 2012, 5-6).

The establishment of standards also appeared to take the determination of what is acceptable out of individual employers' hands. In what can be seen as an acknowledgment of the lack of effective action under earlier regulation the gender pay gap within organisations was represented under the WGE Act as unlikely to be remedied in the absence of strong external regulatory requirements and clear articulation of the type and extent of change intended. 


\section{Pre-print version, article accepted for publication in Australian Journal of}

Political Science

Despite these apparent significant breaks from the past in the formal rules of the new WGE legislation there remain some problematic representations of gender inequality in the WGE Act that were also present in the earlier EOWW Act, with potential to limit the potential for the institution to drive progress towards equal remuneration. As we demonstrate in our analysis in this section the reforms of the WGE Act appear to have been partially successful in that there is increased engagement and promotion of workplace gender equality. However, the embedded gender norms in the formal and informal rules of the legislation that retain the status quo have not been challenged, limiting the potential of the mechanism to provide a strong basis for achieving gender pay equity.

A representation of gender inequality as a problem for business productivity and competitiveness was not only retained in the WGE Act but strengthened. This representation is in the objects of the WGE Act (in section 2A) one of which aims 'to improve the productivity and competitiveness of Australian business through the advancement of gender equality in employment and in the workplace'. With this 'business case' for gender equality represented as a rationale for the WGE Act, arguably the strong opposition expressed by some business groups to the increased reporting requirements is given some legitimacy. There was strong opposition to the new WGE Act by business groups and the conservative coalition political party (both when in opposition and later as governing party) based on an argument that the WGE Act would impose unwarranted costs on business (KPMG 2010; see also Workplace Express 2014). With one rationale for addressing gender equality represented as the improvement of business competitiveness, employers could reasonably argue that action to address gender equality must by weighed up against the costs to business, with this providing a potential justification for taking no action if the costs are seen to be too high. 


\section{Pre-print version, article accepted for publication in Australian Journal of}

Political Science

In the context of considerable hostility in the external environment to the new requirements, the fact that the new WGE Act continued a similar 'light touch' approach to compliance as under the EOWW Act also had the potential to undermine the effectiveness of the reforms. This approach, acknowledged as ineffective under the EOW Act (EOWA 2009; Strachan et al. 2007), entails non-compliant organisations being named in an annual report and potentially being excluded from government grants and contracts. EOWA, the responsible agency, in their submission to a 2009 review of the EOWW Act (KPMG 2009), noted that only an estimated 65-70 per cent of all relevant employers were self-identifying for reporting and named this as a key issue needing to be addressed (EOWA 2009, 3). Nevertheless, despite a similar compliance framework and approach under the WGE there has been a large increase in the number of employers reporting to the agency, up from 2,770 in 2009 (KPMG 2010, 2) to 4,621 in 2017 (Cassells and Duncan 2018, 60), possibly as a result of active identification of relevant employers by EOWA.

Another issue under the EOWW Act was that employers had 'tended to prioritise measures to increase organisational flexibility, while there has been little or no progress in the more difficult areas of pay equity and the promotion and advancement of women' (EOWA 2009, 3). The agency recommended 'making pay equity a separate employment matter, making it mandatory for employers to report on salaries and other pay data' and they recommended 'introducing a requirement for a pay equity review and implementation program' (EOWA 2009: 4). However, while the former recommendation was implemented in the WGE Act, a pay equity review is only required for organisations seeking a citation as a WGEA 'Employer of Choice' (WGEA 2018b). There is no requirement for Employer of Choice citation holders to demonstrate progress in reducing gender pay gaps. 


\section{Pre-print version, article accepted for publication in Australian Journal of Political Science}

Significantly, in the 2015-2016 year only 25 per cent of reporting employers had conducted gender pay gap analyses (WGEA 2016, 16) increasing to 37.7 per cent in 2016-2017 (Cassells and Duncan 2018,6). However, far fewer employers conduct gender pay gap analyses than the 58.5 per cent who report to WGEA that they have a formal equal remuneration policy or strategy (Cassells and Duncan 2018,6), suggesting a gap between policy and practice.

Standardised reporting has enabled the WGEA to publish 'benchmark' reports allowing comparisons of pay data between a large number of industry sectors within industry groups (WGEA 2018b). However, while these reports have attracted strong media interest (e.g. Khadem 2017), there is no strong evidence to suggest the availability of the data will lead to change among those organisations that lack commitment to gender equality, as Smith and Hayes $(2015,21)$ have noted.

The new provision under the WGE Act enabling the responsible government minister to set mandatory minimum standards for employer performance has done little or nothing to support the outcomes focus of the WGE Act. With the actual content of standards left to be determined by the relevant minister there was good opportunity for the incoming conservative Coalition government to move away from the outcomes focus envisaged by the designers of the legislation under the previous Labor government.

In coming to office, the Coalition government maintained the new requirements of the WGE Act, but this was only following strong lobbying by women's groups and some major employers (Gray 2015, 34; Hewett 2014, 2; NFAW 2014). However, there was continuing resistance to the new reporting regime by business groups. For example, in 2014, the 


\section{Pre-print version, article accepted for publication in Australian Journal of Political Science}

Business Council of Australia's CEO Jennifer Westacott stated that the WGE Act was the 'wrong solution to the right problem', and the reporting requirements diverted 'energy and attention from finding more effective solutions, a plethora of poorly conceived regulation is making it so much harder for Australian businesses - small, medium and large - to stay competitive' (Westacott 2014). In response to such concerns the Government announced that it would consult on the 'reporting burden' to businesses under the WGE Act (Workplace Express 2014). By late 2015 the Government stated its expectation of the WGEA under its 'deregulation agenda' was that the Agency look 'for opportunities to reduce compliance costs for business, community organisations and individuals and to contribute to the Government's annual red tape reduction target' (Department of Jobs and Small Business 2015, 1).

The WGE Act reporting requirements on employers remained in place after strong lobbying by women's groups, the Sex Discrimination Commissioner and several large employers (Gray 2015, 34). However, the Coalition government first delayed the establishment of comprehensive industry-specific gender equality standards that had been envisaged under the WGE Act and then legislated a single minimum standard applying only to very large organisations with 500 or more employees and to come into effect from late 2014 (Abetz and Cash 2014). In practice, the standard only requires these employers to put in place one or more strategies that support and improve gender equality in the workplace or implement flexible work arrangements for employees with caring responsibilities or prevent sex-based harassment and discrimination or advance equal remuneration between male and female employees (WGEA 2018d). Employers covered by the standard are able to choose a single aspect of gender equality on which to focus, with one option being a strategy to address equal remuneration. Where advancing equal remuneration is chosen by an employer, there are no 


\section{Pre-print version, article accepted for publication in Australian Journal of Political Science}

specific actions required to demonstrate compliance with the minimum standard beyond having a policy or a strategy (see WGEA 2018d).

Employers who do not want to address the gender pay gap in their organisation do not have to do so under the WGE Act. Despite the significant innovations of the WGE Act the Act's formal rules also assume that the problem should be solved by businesses themselves and that the WGEA role is to assist organisations, rather than to actually enforce legislative requirements. This implicit assumption limits the new institution's potential to drive change as it legitimises the informal rule that compliance is linked only to reporting, not to achieving progress towards gender equality. It remains the case that in practice only those covered employers who are known by the Agency to have refused to report are deemed noncompliant. While organisations can, in theory, also be deemed non-compliant for failing to meet the minimum standards in the WGE Act, it is not possible for organisations to be noncompliant in this regard until the end of the 2016-17 reporting period, four years after the establishment of the legislation (WGEA 2017: 18).

\section{Equal pay in the Fair Work Act 2009}

Equal pay principles have been present in Australian federal IR regulation since 1969 and the principle of equal pay for work of equal value was established in 1972. However, for over two decades, since 1993, there had been no successful equal pay cases in the federal industrial relations (IR) tribunal, largely due to the problem of unequal pay being represented in federal industrial relations legislation as unequal pay due to discrimination. In the Workplace Relations Act 1996 (Cth) (WR Act), the pay equity provisions drew on 


\section{Pre-print version, article accepted for publication in Australian Journal of Political Science}

international conventions on anti-discrimination and equal opportunity and were intended to address sex discrimination. Thus, the equal remuneration powers of the IR tribunal rested on rest on a test of discrimination. The effect of this representation was that a finding of unequal pay required discrimination in wage-setting to be proven. In 2005 the representation of the problem of unequal pay in industrial relations legislation was further narrowed with the introduction by the conservative Coalition government of the 'WorkChoices' amendments to the federal WR Act. The WorkChoices amendments introduced an explicit requirement for reference to be made to a comparator group of male employees before unequal pay could be recognised (See WR Act Pt 12 Div 3, as amended by the Workplace Relations Amendment (Work Choices) Act 2005 (Cth)).. There were no equal pay cases under this legislation.

The introduction of the Fair Work Act 2009 (Cth) (FW Act) by a Labor government brought new promise for the potential of equal pay provisions in IR legislation. The problem to be addressed appeared to be more clearly represented as one of unequal pay outcomes than under previous Commonwealth IR legislation. In the FW Act equal remuneration is defined as 'equal remuneration for men and women workers for work of equal or comparable value' and there is no requirement to show there has been discrimination in wage setting (s 302 (2)). There are several ways equal pay might be advanced through the FW Act with three parts of the Act containing explicit reference to equal remuneration. There is a provision for equal remuneration orders to be made, following an application. There is also a provision that equal remuneration must be taken account of in setting minimum or 'safety net' wages, through annual minimum wage reviews and four-yearly reviews of the industry-based 'Modern Awards' by the Fair Work Commission (FWC). 


\section{Pre-print version, article accepted for publication in Australian Journal of Political Science}

In this section we investigate how equal remuneration is represented in the operations of the FW Act - in the FWC's decisions, and in arguments and submissions made by employers, trade unions and governments. The purpose is to consider the gender norms and possibilities for substantive equality to be progressed through the FW Act as a new institution. We see the promise of the FW Act as residing in the inclusion of the new representation of the unequal pay problem in the formal rules of the Act, a representation that does not rely on a finding of discrimination, suggesting substantive gender equality as the norm. However, based on our analysis of the operations of the Act we conclude the potential for reform has not been met. As with the WGE Act, the design of the gender equality provisions of the FW Act has provided space for resistance to the gender equality reforms. We argue that institutional actors have been able to resist the gender equality innovation and draw on informal rules and old practices, effectively 'forgetting the new' and maintaining existing patterns of power distribution.

\section{The FW Act provision for equal remuneration orders: the equal pay cases}

In 2012 under the new FW Act the FWC made an equal remuneration order for significant pay increases for employees in the highly feminised social and community service (SACS) occupations (Australian Municipal, Administrative, Clerical and Services Union v Australian Business Industrial 2012. 208 IR 446). This was an historic win as the first successful equal pay case in the federal IR jurisdiction for decades (Cortis and Meagher 2012). However, arguably the decision was not underpinned by a change in approach or thinking that might see wider progress for gender pay equity through this mechanism. In this case the FWC did not fully accept an approach that had been taken in a number of successful equal pay cases in Queensland and New South Wales state tribunals which established gender-based 


\section{Pre-print version, article accepted for publication in Australian Journal of Political Science}

undervaluation of work on the basis of a range of indicators, although the FWC did accept there was gender-based undervaluation on the basis that SACS work was care work.

Given the approach taken it there was little sign in the SACS case of a shift in the gender norms of the FWC from those of the earlier tribunals under previous IR legislation that was more restrictive in regard to equal pay. While the FWC employed a limited framing of the concept of gendered undervaluation (Smith and Stewart 2017, 115), it did not appear to adopt an understanding of gender pay inequity as a systemic problem. Further, as the FWC declined trade union applications to establish a set of principles for making equal remuneration orders - as had occurred in state IR jurisdictions - meaning the SACS decision had limited potential to set a precedent for others (Authors 2013, 579; Healy and Kidd 2013, 765). In effect, the decision did little to change the rules of the game to give full effect to the potential of the gender pay reforms in the FW Act that were intended to overcome limitations of the earlier institutions.

A critical factor enabling success in the SACS case appears to have been gaining the endorsement of power holders. In particular, the Federal government (the major funder of social community services, along with state governments) had committed to paying its share of any pay increases awarded (Gillard 2011). It was a decision produced by political mobilization and a willing government (Cortis and Meagher 2012; Todd and Preston 2012) rather than signifying institutional change with a break from the previous restrictive representation of the problem of gender pay equity.

In 2013 a second equal pay case, involving early childhood education and care (ECEC) workers, was launched by two unions: United Voice and the Australian Education Union. 


\section{Pre-print version, article accepted for publication in Australian Journal of Political Science}

There was no support for this equal pay claim from the conservative Coalition government as the main funding body and external power holder. The Government argued against the claim and urged the FWC not to be 'distracted by' equal remuneration principles or earlier case law or inquiries (Commonwealth of Australia 2014, 1). In the proceedings, adopting the 'old' representations of unequal remuneration which had prevented change under earlier equal pay provisions (Smith and Stewart 2014), the Federal government and employers advocated that the unions should identify male comparators in the claim, despite the fact that there is no such requirement in the FW Act. In an interim decision in November 2015, contrary to its earlier decision in the SACS case, the FWC required that equal remuneration applications must reference a comparator which must be of the opposite gender' (Application for an equal remuneration order - United Voice \& Or 2015. 256 IR 362 at 158). The basis for the FWC decision is the argument that the words 'men and women workers' in sections 300 and 302(2) require a comparative task based on gender (Application for an equal remuneration order - United Voice \& Or 2015. 256 IR 362 at 279) The requirement for a comparator to address gender pay inequity returns to an old representation of equality for women as equated to equality to men (Palmer 2002). The FWC's 2015 interim ruling reflects a technical approach to equal remuneration and a rejection of the innovation displayed in states' tribunals in which the adoption of indicators of gender undervaluation enabled a broader representation of the problem of equal pay that provided opportunity for solutions that actually address pay disadvantage of women.

In response to the $2015 \mathrm{FWC}$ decision, the unions sought to rely on a 2005 industrial tribunal decision that linked classifications of childcare and manufacturing workers to establish a comparator for its equal remuneration claim. In early 2018, the FWC rejected the equal pay 


\section{Pre-print version, article accepted for publication in Australian Journal of Political Science}

claim on the basis that the 2005 case was insufficient, in the absence of contemporary evidence to establish metalworkers as an appropriate comparator (Application by United Voice \& the AEU 2018. FWCFB 177).

Despite the new equal remuneration provisions in the FW Act 'a residual and binary default remains, namely that equality for women can only be claimed against a series of explicit and implicit masculinised benchmarks' (Smith and Stewart 2017, 133). The FWC's approach in the ECEC case could be characterised as rejection of gender-based undervaluation as a means of assessing whether the objective of equal remuneration is met (Smith and Stewart 2017, 131) or as a reading of the reference in the FW Act to 'equal remuneration between men and women' as necessitating a male comparator, as by the FWC. However, either way it is understood, it provides an outcome that is much less risky and disruptive to the government and to business as it maintains the status quo in an environment in which there is little support for sector-wide change from the power holders.

In response to ambiguities in the FW Act's equal remuneration provisions revealed in the FWC's interpretation in the ECEC case, in 2017 a Senate inquiry into gender segregation recommended reforms to the FW Act. These included introducing gender pay equity as an overall object of the Act and clarifying that applications may be made without the need for a direct male comparator to establish undervaluation (Parliament of Australia 2017, 59-60). Importantly these and other recommendations go to the operations of the FW Act and include the provision of guidance for both FWC and applicant parties. To date, the Federal government has not responded to these or other recommendations of the Senate inquiry. At 


\section{Pre-print version, article accepted for publication in Australian Journal of Political Science}

the time of writing the ECEC case continues with the unions seeking a suitable male comparator.

\section{Equal remuneration in annual wage and modern award reviews}

Equal remuneration is included among the guiding principles the FWC must 'take account' of in carrying out its Modern Award and minimum wage fixing functions (FW Act s 134; s 284). The inclusion of equal remuneration in these two parts of the FW Act formally embeds a concern for equal pay in some of the Act's key wage-setting mechanisms and represents the unequal pay problem as a problem of industry and occupational segregation and of the undervaluation of women's work (Authors 2013), not as a narrower problem of direct discrimination as it has been represented in former IR legislation. However, when we examine the operations of the FW Act, it is clear that the representation of unequal pay as a systemic problem historically embedded in wage-fixing practices is not taken up by the institutional actors.

The FWC reviews minimum wages annually for employees in the lowest-paid jobs and for employees who are 'award-reliant' as they have been unable to engage in collective bargaining for higher wages. With women over-represented in low-paid jobs and among award-reliant employees, any increases in minimum wages and reductions in overall wage inequality are likely to be positive for reducing the gender pay gap. In addition, in many lowpaid and feminised industries wages in the collectively bargained enterprise agreements are closely tied to minimum award rates, meaning that minimum wage increases can have a wider impact. 


\section{Pre-print version, article accepted for publication in Australian Journal of Political Science}

An analysis of the first four years of operation of the FW Act (to 2013) concluded that the unequal pay problem was represented by the main institutional actors (the FWC, government, employers and trade unions) as somewhat peripheral to annual wage review considerations and confined to 'concerns that the award rates system should not worsen or might improve the gender pay gap' rather than there being a 'commitment to a system of award classification rates that would support equal remuneration' (Authors 2013, 583). Since then equal remuneration in the FW Act has received greater attention, following the establishment in 2013 of a Pay Equity Unit (implementing a recommendation of a 2009 House of Representatives pay equity inquiry) to undertake research to support the work of the FWC.

The FWC annual wage reviews from 2014 to 2016 include many more pages devoted to equal remuneration than the earlier reviews, including in submissions from some employers, governments and trade unions and in the FWC's decisions. However, these recent wage reviews have proceeded pretty much in the same way as the earlier ones in relation to most actors' representations of unequal pay and in the FWC's approach.

There is a strong representation of the problem as a problem best addressed through processes other than minimum wage determinations. Reading the text of the FWC 2016 minimum wage decision, it appears that once the FWC is satisfied there is no evidence of 'discrimination'by which it is meant there is no difference between the wages of award-reliant men and women who have the same levels of education, are in the same industry, occupation and size and type of business - the FWC's interest in equal remuneration is merely as one 'factor in favour of an increase in (minimum wages)' (FWC 2016, 125-126). Submissions by the main employer groups are either silent on equal remuneration (e.g. Australian Business Industrial 2016; Australian Chamber of Commerce and Industry 2016) or in accord with the FWC in 


\section{Pre-print version, article accepted for publication in Australian Journal of}

Political Science

their explicit dismissal of the idea there might be an equal remuneration problem that could be addressed through minimum wage-setting (Australian Industry Group 2016, 28). While the ACTU (2016) argued minimum wage increases would be helpful in reducing the gender pay gap, the Federal government argued the process was 'a blunt tool for addressing the complex factors underlying gender pay inequality' (Australian Government 2016, 64). This problem representation separates current unequal pay outcomes from the multiple factors that may have led to these outcomes and insists these factors be discovered before inequality can be addressed. The government submission also cites the goal of 'gender equality' in arguing against a minimum wages increase, stating an increase could undermine gender equality through 'jeopardis(ing) female employment' (Australian Government 2016, 64).

So, despite a formal representation of equal remuneration in the FW Act that explicitly rejects a need to demonstrate discrimination (House of Representatives 2008, 189, 1192) and that is concerned with remuneration of 'work of equal or comparable value' (our emphasis), some of the main policy actors have continued to represent the problem as it was represented under the previous institutions. While the employer peaks and Federal government representations might reflect resistance to the gender reform in itself, maintaining the status quo and representing the problem in old ways (requiring proof of discrimination or requiring a male comparator) also ensures that gender equality goals do not work to undermine broader arguments these actors were making for minimising wage rises. In this, and to the extent that the FWC decision accords with the arguments of key power holders in the external environment (including the Federal government), the constraints on change through the gender reforms contained in this part of the FW Act are evident. Capacity for reform is limited in the absence of any strong impetus for change or challenge to maintaining old 


\section{Pre-print version, article accepted for publication in Australian Journal of Political Science}

norms and ways of operating that were present when equal remuneration had no role in minimum wage cases.

The FWC also conducts four-yearly reviews of the Modern Awards that contain safety net wages and, in these processes, equal remuneration appears to have similarly been resisted and sidelined. The initial 'award modernisation' process that took place with the establishment of the FW Act and introduced Modern Awards in place of a much larger number of industrial awards does not appear to have included any consideration of equal remuneration at all (Junor, Hammond and Taksa 2009, 6). Inspection of submissions to the next review process, which commenced in 2014, shows the major employer peak bodies dismissed the issue in one bold stroke. They argued that as they couldn't find that any party (employers or trade unions) had sought to change a classification structure or pay rate due to pay equity reasons during the award modernisation process there was no basis for assuming classification or rates in any Modern Awards are in any way 'infected with gender based inequity' (Australian Business Lawyers and Advisors 2014, 8). In a decision that is part of this review process the FWC again took a very narrow view of equal remuneration in the FW Act in arguing that cutting penalty rates that are paid for Sunday work in the hospitality, retail, fast food and pharmacy sectors would not disproportionately affect women, despite the concentration of women in low-paid jobs in these service industries. The FWC $(2017,48)$ argued that, even if it was shown that a reduction in penalties would worsen the gender pay gap, this would not necessarily be relevant to the equal remuneration requirements of the legislation.

\section{Conclusion}




\section{Pre-print version, article accepted for publication in Australian Journal of Political Science}

The WGE Act, despite appearing to be a significantly different and more powerful institution for gender equality than its predecessor, retains some formal elements that provide legitimacy to the challenges of actors who resist the innovation. The design of the WGE Act has left space for effective resistance to its gender reforms and this has been exploited, including through the conservative Coalition government's modifications to the 'newness' of the institution in the establishment of a single minimum standard. Similarly, external power holders appear to have been significant for the effectiveness of the gender reforms of the FW Act. In the first (SACS) equal pay case, in the context of strong support from the Federal government, the FWC went some way to adopting a 'new' approach to gender pay inequity. However, the FWC in the second equal pay case, without the support of the Federal government, institutional actors actively resisted adopting a new understanding of unequal pay despite the opportunity to do so that is provided within the text of the FW Act and the precedents set in states' tribunals. Instead, supported by the legacies of the old institutions, and faced with ambiguities in the legislation the FWC has maintained old representations that do not disrupt long-standing gender norms. No significant gender equality change has resulted from the central place given to equal pay in the wage-setting and Modern Awards provisions of the FW Act. The likelihood for further breaks with the past in the operations of the WGE Act and FW Act to progress gender equality is not high, as practices may now be set, constraining institutional capacity for further change. While the advent of both institutions has brought some positive change for gender equality, future success may require concerted action by gender equality activists for further legislative and administrative reforms.

\section{References}


Pre-print version, article accepted for publication in Australian Journal of $\underline{\text { Political Science }}$

Abetz, Eric and Cash, Michaelia. 2014. Minimum Standard for Gender Equality Joint Media Release 25 March 2014. Minister's Media Centre. Canberra.

https://ministers.jobs.gov.au/abetz/minimum-standard-gender-equality.

Australian Business Industrial. 2016. Annual Wage Review 2015-16, Submissions of Australian Business Industrial and the NSW Business Chamber Ltd.

https://www.fwc.gov.au/awards-agreements/minimum-wages-conditions/annual-wagereviews/annual-wage-review-2015-16-0.

Australian Business Lawyers and Advisors. 2014. Reply Submissions on the Legislative and Conceptual Framework, Equal Remuneration Case C2013/5139 and C2013/6333).

https://www.fwc.gov.au/documents/sites/caeremuneration/submissions/ab-sumissions-4-apr2014.pdf.

Australian Chamber of Commerce and Industry. 2016. Annual Wage Review: 2015-2016. https://www.fwc.gov.au/awards-agreements/minimum-wages-conditions/annual-wagereviews/annual-wage-review-2015-16-0.

Australian Council of Trade Unions (2009) Submission of the Australian Council of Trade Unions (ACTU) to the Review of the Equal Opportunity for Women in the Workplace Act and Agency. Melbourne: ACTU.

Australian Council of Trade Unions. 2016. ACTU Submission Annual Wage Review 2015-16. Melbourne: ACTU. https://www.fwc.gov.au/awards-agreements/minimum-wagesconditions/annual-wage-reviews/annual-wage-review-2015-16-0. 
Pre-print version, article accepted for publication in Australian Journal of $\underline{\text { Political Science }}$

Australian Government. 2016. Submission to the Fair Work Commission Annual Wage Review 2016. https://www.fwc.gov.au/awards-agreements/minimum-wagesconditions/annual-wage-reviews/annual-wage-review-2015-16-0.

Authors 2013; 2015

Bacchi, Carol. 2016. "Introducing the 'What's the problem represented to be approach?' "In Poststructural Policy Analysis: A Guide to Practice, edited by Carol Bacchi and Susan Goodwin, 21-24. New York: Palgrave Macmillan.

Bacchi, Carol. 1999. Women, Policy and Politics: The Construction of Policy Problems. London: Sage Publications.

Cassells, Rebecca and Duncan, Alan (2018), 'Gender Equity Insights 2018: Inside Australia’s gender pay gap', BCEC|WGEA Gender Equity Series, Issue 3, March. Perth: Curtin University.

Commonwealth of Australia 2014 Submission for the Commonwealth of Australia in the Application by United Voice and Australian Education Union C2013/5139 and Application by Independent Education Union Of Australia C2013/633324 February. Fair Work Commission. https://www.fwc.gov.au/documents/sites/caeremuneration/submissions/agscoa-submissions-24-feb-2014.pdf 
Pre-print version, article accepted for publication in Australian Journal of $\underline{\text { Political Science }}$

Cortis, Natasha, and Gabrielle Meagher. 2012 "Recognition at last: Care work and the equal remuneration case." Journal of Industrial Relations 54(3): 377-385.

Department of Jobs and Small Business. 2015. 'Statement of expectations, Workplace Gender Equality Agency’. 4 December. https://docs.jobs.gov.au/documents/workplacegender-equality-agency-statement-expectations.

Equal Opportunity for Women in the Workplace Agency [EOWA]. (2009). Submission to the Review of the Equal Opportunity for Women in the Workplace Act and Agency. https://www.wgea.gov.au/sites/default/files/EOWA_review_Sub_Exec_Sum-2009_tag.pdf.

European Commission. 2009. The Gender Pay Gap from a Legal Perspective. European Network of Legal Experts In the Field of Gender Equality, Directorate-General for Employment, Social Affairs and Equal Opportunities, Brussels: European Commission.

Fair Work Commission. 2015. Equal Remuneration Decision 2015. 30 November Melbourne: Fair Work Commission.

Fair Work Commission. 2016. Decision: Annual Wage Review 2015-16 (C2016/1). 31 May. Melbourne: Fair Work Commission.

Fair Work Commission. 2017. Decision: 4 Yearly Review of Modern Awards - Penalty Rates (AM2014/305). 23 February. Melbourne. Fair Work Commission. 
Pre-print version, article accepted for publication in Australian Journal of $\underline{\text { Political Science }}$

Fredman, Sandra. 2008. Human Rights Transformed: Positive Rights and Positive Duties.

Oxford: Oxford University Press.

Gillard, Julia. 2011. Gillard Government to Deliver Historic Payrise for Social and

Community Workers. Media Release, 10 November. http://pmtranscripts.pmc.gov.au/.

Gray, Joanne. 2015. "Gender champion keeps her cool.” The Australian Financial Review, 8 May.

Healy, Joshua and Michael. P. Kidd. 2013 “Gender-based undervaluation and the equal remuneration powers of Fair Work Australia." Journal of Industrial Relations 55(5) 760-782.

Hewett, Jennifer, 2014. "Gender reporting under threat" The Australian Financial Review, 26 February 2014, 2.

House of Representatives. 2008. Fair Work Bill 2018 Explanatory Memorandum, Canberra: The Parliament of the Commonwealth of Australia.

Junor, Anne, Susan Hammond, and Taksa, Lucy. 2009. "Forward with (Gender Pay) Fairness?" Paper presented at Labour, Capital and Change: The $23^{\text {rd }}$ Conference of the Association of Industrial Relations Academics of Australia and New Zealand, Newcastle, Australia, 4-6 February.

Khadem, Nassim. 2017. 'Men out-earn women by more than \$26,500: WGEA 2017 gender pay gap report' Sydney Morning Herald, 16 November. 
Pre-print version, article accepted for publication in Australian Journal of $\underline{\text { Political Science }}$

KPMG. 2010. Review of the Equal Opportunity for Women in the Workplace Act 1999 Consultation Report. Canberra: Office for Women, Department of Families, Housing, Community Services and Indigenous Affairs.

Krook, Mona L. and Fiona Mackay. 2011. "Introduction: Gender, politics, and institutions." In Gender, Politics and Institutions: Towards a Feminist Institutionalism, edited by Mona L. Krook and Fiona Mackay. Houndmills, Basingstoke: Palgrave Macmillan, 1-41.

Mackay, Fiona. (2009) “Institutionalising 'new politics' in post devolution Scotland: 'nested newness' and the gendered limits of change." European Conference on Politics and Gender, Queen's University Belfast, 21-23 January.

Mackay, Fiona. 2014. 'Nested newness, institutional innovation, and the gendered limits of change.' Politics \& Gender, 10: 549-571.

Mackay, Fiona, Meryl Kenny and Louise Chappell. 2010. "New institutionalism through a gender lens: Towards a feminist institutionalism?” International Political Science Review, 31(5): 573-588.

Merritt, Chris. 2012. "Law will Force Firms to Disclose Gender Equality Results." The Australian, 7 December, 33. 
Pre-print version, article accepted for publication in Australian Journal of $\underline{\text { Political Science }}$

National Foundation of Australian Women [NFAW]. 2014. Briefing paper on the Exposure

Drafts for the Workplace Gender Equality Agency Act 2012,

www.nfaw.org/wp.../03/WGEA-Briefing-Paper-Gender-Reporting-March-2014.doc.

O’Reilly, Jacqueline, Mark Smith, Simon Deakin and Brendan Burchell. 2015. "Equal pay as a moving target: International perspectives on forty-years of addressing the gender pay gap.” Cambridge Journal of Economics 39(2): 299-331.

Parliament of Australia. 2009. Making it Fair: Pay Equity and Associated Issues related to Increasing Female Participation in the Workforce. Canberra: House of Representatives.

Parliament of Australia. 2010. Equal Opportunity for Women in the Workplace Amendment Bill 2012 Explanatory Memorandum. Canberra: House of Representatives.

Parliament of Australia. 2016. A Husband is not a Retirement Plan: Achieving Economic Retirement for Women. April. Canberra: The Senate Economics Reference Committee.

Parliament of Australia. 2017. Gender Segregation in the Workplace and its Impact on Women's Economic Equality. Canberra: The Senate Standing Committee on Finance and Public Administration.

Pierson, Paul. 2004. Politics in Time: History, Institutions, and Social Analysis, Princeton, NJ: Princeton University Press. 
Pre-print version, article accepted for publication in Australian Journal of $\underline{\text { Political Science }}$

Rimmer, Susan H., and Marian Sawer. 2016. "Neoliberalism and gender equality policy in Australia.” Australian Journal of Political Science, 51(4): 742-758.

Rubery, Jill, and Aristea Koukiadaki. 2016. Closing the Gender Pay Gap: A Review of the Issues, Policy Mechanisms and International Evidence. Geneva: International Labour Office.

Schmidt, Vivien A. 2010. "Taking ideas and discourse seriously: Explaining change through discursive institutionalism as the fourth "New Institutionalism"." European Political Science Review 2: 1-25.

Smith, Belinda and Monica Hayes. 2015. "Using data to drive gender equality in employment: More power to the people?" Australian Journal of Labour Law 28(3), 191-213.

Smith, Meg, and Andrew J. Stewart. 2014. "Equal remuneration and the Social and Community Services case: progress or diversion on the road to pay equity?" Australian Journal of Labour Law 27(1):31-56.

Smith, Meg and Andrew J. Stewart. 2017. Shall I compare thee to a fitter and turner? The role of comparators in pay equity regulation. Australian Journal of Labour Law, 30(2): 113136.

Stewart, Andrew, Anthony Forsyth, Mark Irving, Richard Johnstone and Shae McCrystal. 2016. Creighton \& Stewart's Labour Law, 6th edn, Sydney: Federation Press. 
Pre-print version, article accepted for publication in Australian Journal of $\underline{\text { Political Science }}$

Strachan, Glenda, John Burgess, and Lindy Henderson. 2007. "Equal employment opportunity legislation and policies: the Australian experience." Equal Opportunities International 26(6): 525-540.

Sutherland, Carolyn. 2013. "Reframing the Regulation of Equal Employment Opportunity: The Workplace Gender Equality Act 2012." Australian Journal of Labour Law 26(1) 102111.

Todd, Patricia and Alison Preston. 2012. "Gender pay equity in Australia: Where are we now and where are we heading?" Australian Bulletin of Labour 38 (3): 251.

Westacott, Jennifer. 2014. “Good process avoids poor regulation”. The Australian Financial Review 24 February. http://www.bca.com.au/media/good-process-avoids-poor-regulationarticle-by-jennifer-westacott-in-the-afr/view-all-related-publications.

Whitehouse, Gillian. 2001. "Recent trends in pay equity: Beyond the aggregate statistics." Journal of Industrial Relations 43(1): 66-78.

Workplace Express. 2014. "Canberra seeking feedback on gender reporting "burden" May 15. https://www.workplaceexpress.com.au.

Workplace Gender Equality Agency. 2012. What's Changing? Sydney:

WGEA.https://www.wgea.gov.au/sites/default/files/Branded_WGEA_whats_changing.pdf' 
Pre-print version, article accepted for publication in Australian Journal of $\underline{\text { Political Science }}$

Workplace Gender Equality Agency. 2016. Our Consultation.

https://www.wgea.gov.au/about-wgea/consultation.

Workplace Gender Equality Agency. 2017. Progress Report 2014-16 to the Minister. Sydney: WGEA.

Workplace Gender Equality Agency. 2018a. Australia's gender pay gap statistics, Sydney: WGEA.

Workplace Gender Equality Agency. 2018b. WGEA Data Explorer. WGEA.

http://data.wgea.gov.au/industries/1\#pay_equity_content, accessed 1 May 2018.

Workplace Gender Equality Agency. 2018c. Guide to Citation: WGEA Employer of Choice for Gender Equality, Sydney: WGEA.

Workplace Gender Equality Agency. 2018d. What are minimum standards? Sydney: WGEA. https://www.wgea.gov.au/minimum-standards/what-are-minimum-standards, accessed 1 May 2018. 